\title{
PEMANFAATAN MEDIA KAHOOT DALAM PEMBELAJARAN KETERAMPILAN MENDENGARKAN BAHASA ARAB DI IAI SUNAN KALIJOGO MALANG
}

\author{
Achmad Busiri1) \\ 1)IAI Sunan Kalijogo Malang \\ 1)
}

\begin{abstract}
Abstrak: Pandemi Covid-19 yang melanda dunia berpengaruh pada berbagai aspek kehidupan. Aspek Para Dosenan pun juga berpengaruh yaitu adanya kebijakan untuk belajar dirumah. Seluruh aktivitas disekolah terhenti dan berpindah dengan konsep pembelajaran berbasis online menggunakan beberapa platform digital atau aplikasi pembelajaran di android maupun laptop. Sebagai Para Dosen yang memiliki peran penting dalam pengembangan inovasi, ide atau gagasan untuk pemanfaatan teknologi dalam pembelajaran online. Salah satu dari beberapa platform digital yaitu platform kahoot yang merupakan platform berbasis kuis online, dimana para mahasiswa dapat merefleksikan langsung jawaban secara online dan kahoot mencatat semua aktivitas siswa yang dapat menjadi bahan resume penilaian bagi Para Dosen. Penggunaan aplikasi kahoot selain dapat menampilkan teks materi pelajaran juga dapat memunculkan video yang terkoneksi dengan youtube dalam hal ini dapat menjadi media pembelajaran terutama bahasa asing untuk keterampilan mendengarkan. Bahasa Arab merupakan salah satu bahasa asing yang juga mengajarkan empat keterampilan yaitu keterampilan berbicara, mendengarkan, membaca, dan menulis. Keterampilan mendengarkan yang dimaksudkan yaitu sebagai kemampuan Mahasiswa untuk memahami bunyi/ujaran dalam bahasa Arab dengan baik dan benar. Pembelajaran bahasa Arab menggunakan platform kahoot dalam keterampilan mendengarkan di era pandemi ini memiliki beberapa kelebihan, diantaranya: 1) Penggunaan platform kahoot menjadi salahsatu inovasi pembelajaran yang sangat menarik dan interaktif, 2) sesuai kreatifitas dan inovasi dalam membuat kuis keterampilan mendengarkan bahasa Arab, 3) Mahasiswa dapat mengerjakan kuis keterampilan mendengarkan dengan mudah karena video terhubung dengan youtube dan dapat diulang lebih dari satu kali, 4) Mahasiswa dan Para Dosen dapat memantau hasil ranking dari kuiz kahoot yang berlangsung secara online dan ditampilkan dari layar gawai sehingga antar Mahasiswa saling kompetitif untuk menjadi yang terbaik.
\end{abstract}

Kata Kunci: Media Kahoot, Keterampilan Mendengarkan

Abstract: The Covid-19 pandemic that has hit the world has affected various aspects of life. The aspect of the lecturers is also influential, namely the existence of a policy to study at home. All activities at school stop and move with the 


\section{muhadasah \\ Jurnal Pendidikan Bahasa Arab \\ INSTITUT AGAMA ISLAM SUNAN KALIJOGO MALANG \\ P-ISSN 2622-6723 E-ISSN 2721-9488 \\ Volume 2, Nomor 2 Desember 2020}

concept of online-based learning using several digital platforms or learning applications on Android or laptops. As Lecturers who have an important role in developing innovation, ideas or ideas for the use of technology in online learning. One of the several digital platforms is the kahoot platform which is an online quiz-based platform, where students can directly reflect on the answers online and kahoot records all student activities which can be used as assessment resume material for lecturers. The use of the kahoot application besides being able to display the text of the subject matter can also bring up videos connected to YouTube in this case it can be a learning medium, especially foreign languages for listening skills. Arabic is a foreign language that also teaches four skills, namely speaking, listening, reading and writing skills. Listening skills are intended as the ability of students to understand sounds / utterances in Arabic properly and correctly. Learning Arabic using the kahoot platform in listening skills in this pandemic era has several advantages, including: 1) The use of the kahoot platform is one of the most interesting and interactive learning innovations, 2) according to creativity and innovation in making Arabic listening skills quizzes, 3) Students can do the listening skills quiz easily because the video is connected to YouTube and can be repeated more than once, 4) Students and Lecturers can monitor the results of the ranking of the kahoot quiz which takes place online and is displayed on the device screen so that students are competitive to become the best.

Keywords: Media Kahoot, Listening Skills 


\section{muhadasah \\ Jurnal Pendidikan Bahasa Arab \\ INSTITUT AGAMA ISLAM SUNAN KALIJOGO MALANG \\ P-ISSN 2622-6723 E-ISSN 2721-9488 \\ Volume 2, Nomor 2 Desember 2020}

\section{PENDAHULUAN}

Pandemi Covid-19 yang melanda dunia juga menggemparkan Indonesia seperti artikel yang ditulis oleh Pranita, Ellyvon dari berita digital Kompas bahwa tanggal 02 Maret 2020, untuk pertama kalinya pemerintah mengumumkan dua kasus pasien positif Covid-19 di Indonesia. Namun, Pakar Epidemiologi Universitas Indonesia (UI) Pandu Riono menyebutkan virus corona jenis SARS-CoV-2 sebagai penyebab Covid-19 itu sudah masuk ke Indonesia sejak awal Januari. Pandemi Covid-19 ini juga berpengaruh pada berbagai aspek kehidupan, Bahkan dalam aspek Para Dosenan pun juga berdampak pada kebijakan pelajar untuk belajar dirumah. Seluruh aktivitas disekolah terhenti dan berpindah dengan konsep pembelajaran berbasis online menggunakan beberapa platform digital atau aplikasi pembelajaran di android maupun laptop. Para Dosen memiliki peran penting dalam pengembangan inovasi, ide atau gagasan untuk pemanfaatan teknologi dalam pembelajaran online. Teknologi informasi menjadi peran perting dalam pembelajaran online. Salah satu contoh dari teknologi informasi yaitu $e$ learning. Pembelajaran yang dilaksanakan dengan adanya jarak jauh maka menggunakan e-learning dengan pendampingan orang tua. Dengan begitu tujuan Para Dosenan yang efektif dalam era pandemi seperti ini tetap bisa tercapai.

Para Dosen yang efektif tentunya dibutuhkan interaksi antar Para Dosen dan Mahasiswa. Aplikasi pembelajaran e-learning yaitu adanya platform digital yang interaktif banyak bermunculan diantaranya ruang guru, google for education, google classroom, whatsapp group, dan video conference. Sedangkan di aplikasi permainan pembelajaran atau gamebased learning ada yang bernama kahoot. Pengertian dari gamebased learning itu sendiri yaitu media yang berbasis permainan dan dapat meningkatkan potensi dan kualitas belajar. Game based learning juga merupakan salah satu cara untuk meningkatkan kolaborasi Para Dosen dan Mahasiswa dalam pembelajaran hal ini dikemukakan oleh A. R. Putri dalam Kaunang. ${ }^{1}$

1 Di akses pada tanggal 09 Oktober 2020 \& jam 20.00 WIB di alamat http://ejournal.unima.ac.id/index.php/dilan/article/view/2090/1309. Kaunang, S. 2020. Model Pembelajaran Menarik Dengan Menggunakan Aplikasi Kahoot Sebaagai Bahan Evaluasi Keberhasilan Belajar Untuk Mahasiswam hlm.43. 


\section{muhadasah \\ Jurral Panditikan Bahass arab \\ INSTITUT AGAMA ISLAM SUNAN KALIJOGO MALANG \\ P-ISSN 2622-6723 E-ISSN 2721-9488 \\ Volume 2, Nomor 2 Desember 2020}

Salah satu dari beberapa platform digital game based learning yaitu platform kahoot yang merupakan platform berbasis kuis online, dimana siswa dapat merefleksikan langsung jawaban secara online dan kahoot mencatat semua aktivitas mahasiswa yang dapat menjadi bahan resume penilaian bagi Para Dosen. Kahoot memiliki fungsi atensi yang menjadi media visual merupakan inti, menarik dan mengarahkan perhatian pembelajaran untuk berkosentrasi kepada isi pelajaran yang berkaitan dengan makna visual yang ditampilkan atau menyertai teks materi pelajaran. ${ }^{2}$ Aplikasi pembelajaran kahoot adalah aplikasi berbasis games atau permainan yang menjadi media efektif, menyenangkan, dan tidak membosankan untuk Mahasiswa. Penggunaan aplikasi kahoot selain dapat menampilkan teks materi pelajaran juga dapat memunculkan video yang terkoneksi dengan youtube dalam hal ini dapat menjadi media pembelajaran bahasa.

Penggunaan media kahoot dalam proses belajar mengajar memiliki beberapa manfaat diantaranya: 1) Pembelajaran akan lebih menarik perhatian Mahasiswa sehingga dapat menumbuhkan minat dan motivasi belajar, 2) Tujuan pembelajaran akan tercapai dengan baik karena disajikan lebih jelas sehingga Mahasiswa mudah memahami materi, 3) Memunculkan variasi metode pembelajaran bagi Para Dosen, 4) Mahasiswa akan lebih banyak melakukan interaksi dalam kegiatan belajar dan media kahoot yang berbasis kuis ini memacu jiwa kompetitif antar Mahasiswa.

Bahasa Arab merupakan salah satu bahasa asing yang juga mengajarkan empat keterampilan yaitu maharoh 'istima'(mendengarkan), maharoh qiro'ah (membaca), dan maharoh kitabah (menulis). Keempat unsur ini tentu saling berhubungan, akan tetapi memiliki perbedaan yang signifikan dalam prosesnya. Keterampilan mendengarkan yaitu sebagai kemampuan Mahasiswa untuk memahami bunyi/ujaran dalam Bahasa Arab dengan baik dan benar. Pembelajaran keterampilan mendengarkan membutuhkan peralatan (device) sumber belajar yang dirancang: papan tulis, white board, kapur,

2 Di akses pada tanggal 10 Oktober 2020 \& jam 19.50 WIB di alamat https://ilmupendidikan.net/pembelajaran/media-pembelajaran/fungsi-fungsi-utama-media-pembelajaran-visual. Imran.S. 2014. Fungsi-Fungsi Utama Media Pembelajaran Visual. https://ilmupendidikan.net/pembelajaran/media-pembelajaran/fungsi-fungsi-utama-media-pembelajaran-visual 
spidol, OHP. LCD, slides, film TV, video player dan lain lain. ${ }^{3}$ Pembelajaran keterampilan mendengarkan bahasa Arab di era pandemi ini tetap berjalan tanpa banyak peralatan yang dibuuthkan hanya gawai, laptop, atau PC.

Dengan adanya wabah ini fenomena pembelajaran keterampilan berbahasa berbasis online, Mahasiswa di Kampus IAI Sunan Kalijogo Malang yang biasanya melaksanakan pembelajaran empat keterampilan itu dengan offline maka salahsatu media aplikasi kahoot menjadi salah satu solusi yang dibutuhkan. Untuk meningkatkan efektivitas serta kualitas proses pembelajaran keterampilan mendengarkan dimana proses pembelajaran meningkatkan kualitas hasil belajar Mahasiswa dibutuhkan penggunaan media pembelajaran kahoot dalam proses belajar mengajar dan evaluasi belajar Mahasiswa. Artikel ini akan mendeskripsikan pembelajaran keterampilan berbahasa Arab pada mahasiswa di kampus IAI Sunan Kalijogo Malang Malang. Salah satu keterampilan berbahasa yang dideskripsikan artikel ini yaitu keterampilan mendengarkan dengan media kahoot berbasis online pada era pandemi saat ini.

\section{METODE PENELITIAN}

Pendekatan yang penulis gunakan dalam penelitian ini adalah penelitian kualitatif deskriptif, yaitu penelitian yang menggunakan latar alamiah dengan maksud menafsirkan fenomena yang terjadi dan melakukan dengan jalan melakukan berbagai metode yang ada. ${ }^{4}$

Selain itu Juga, David William berpendapat bahwa pendekatan kualitatif adalah pengumpulan dan dalam suatu latar alamiah dengan menggunakan metode alamiah dan dilakukan oleh orang atau peneliti yang tertarik secara alamiah. ${ }^{5}$ Dan metode penelitian kualitatif sering disebut metode penelitian naturalistik karena penelitiannya dilakukan pada kondisi yang alamiah (natural setting). Oleh karena itu, teknik pengumpulan data yang digunakan dalam penelitian ini adalah:

3 Nur Sholeh dan Ulin Nuha, 2013. Pengembangan Kurikulum Bahasa Arab. Jogjakarta. Diva Press, 2013), hlm.217

4 Lexy J, Moeleong. Metode Penelitian Kualilatif. (Bandung: Remaja Rosdakarya, 2015), hal. 5.

5 Moleong. Metodologi Penelitian Kualitatif. (Bandung: Rosdakarya, 2002), hal. 7. 


\section{a. Observasi}

Suatu alat pengumpulan data yang dilakukan dengan mengamati dan mencatat secara sistematik gejala-gejala yang diselidiki. Sedangkan menurut Nasution, observasi adalah dasar semua ilmu pengetahuan. Para ilmuwan hanya dapat bekerja berdasarkan data, yaitu fakta mengenai dunia kenyataan yang diperoleh melalui observasi. ${ }^{6}$

b. Wawancara

Wawancara ini dilakukan oleh dua pihak yaitu pewawancara (interviewer) yang mengajukan pertanyaan dan terwawancara (interviewee) yang memberikan jawaban atas pertanyaan itu. ${ }^{7}$

Wawancara (interview) merupakan alat pengumpulan data atau informasi dengan tanya jawab sepihak yang dikerjakan dengan sistematis dan berlandaskan pada tujuan penelitian. Maka dapat kita simpulkan bahwa wawancara adalah proses tanya jawab dalam penelitian dimana dua orang atau lebih bertatap muka mendengarkan secara langsung informasi atau keterangan.

Setelah data terkumpul peneliti akan melakukan analisis data dengan mengelompokkan data-data yang diperoleh yang kemudian dianalisis. Analisis data kualitatif dilakukan dengan jalan bekerja dengan data, mengorganisasikan data, memilah-milihnya menjadi satuan yang dapat dikelola, mensistensikannya, mencari dan menemukan pola, menemukan apa yang penting dan apa yang dipelajari, dan memutuskan apa yang dapat diceritakan kepada orang lain. ${ }^{8}$ Analisis data ini dilakukan untuk menjawab pertanyaan penelitian atau untuk mengkaji hipotesis penelitian yang telah dinyatakan sebelumnya.

Data yang telah terkumpul perlu dianalisis dengan cermat dan teliti, sehingga dapat menemukan kesimpulkan yang obyektif dalam penelitian tersebut. Pendekatan yang digunakan dalam penelitian ini bersifat kualitatif dengan tehnik "analisis induktif". ${ }^{9}$

\footnotetext{
${ }^{6}$ Nasution. Metode Penelitian Naturalistik Kualitatif. (Bandung: Tarsito, 2007), hal. 56.

${ }^{7}$ Dedy Mulyana, Metodologi Penelilian Kualitatif. (Bandung: Rosdakarya, 2013), hal. 180.

${ }^{8}$ Moleong. Metode Penelitian Kualilatif. (Bandung: Remaja Rosdakarya, 2010), hal. 248.

${ }^{9}$ Bagong Suyanto Sutinah, Metode Penelitian Sosial: Berbagai Alternatif Pendekatan, (Jakarta: Kencana, 2005), hal. 69.
} 
Berdasarkan pengertian di atas dapat disimpulkan bahwa menganalisa data dilakukan dengan cara mengumpulkan data, mengorganisasikan data, memilah-milihnya menjadi satuan yang dapat dikelola data sehingga mudah untuk dibaca. Dengan demikian, maka dalam penelitian peneliti menggunakan analisa data induktif dengan mengolah data yang ada kaitannya dengan penggunaan metode membaca dalam pembelajaran Bahasa Arab.

\section{HASIL DAN PEMBAHASAN}

\section{Media Pembelajaran Online di Era Pandemi Covid-19}

Pandemi Covid-19 menurut website Wikipedia berawal dari wabah Covid-19 dideteksi di kota Wuhan, provinsi Hubei, Tiongkok pada tanggal 1 Desember 2019, dan ditetapkan sebagai pandemi oleh Organisasi Kesehatan Dunia (WHO) pada tanggal 11 Maret 2020. Hingga 17 September 2020, lebih dari 29.864 .555 orang kasus telah dilaporkan lebih dari 210 negara dan wilayah seluruh dunia, mengakibatkan lebih dari 940.651 orang meninggal dunia dan lebih dari 20.317 .519 orang sembuh. Upaya untuk mencegah penyebaran virus ini yaitu melakukan pembatasan perjalanan, karantina, pemberlakuan jam malam, penundaan dan pembatalan acara, serta penutupan fasilitas. Hal ini kemudian menjadi awal pemicu adanya sekolah online dengan pembelajaran online serta pengurangan jam belajar dalam artian agar mahasiswa dapat istirahat dan menjaga kesehatan. Fenomena ini berdampak pada ketidaksiapan orangtua, para Dosen dan Mahasiswa karena semua berbasis online. Lingkungan rumah dan disekolah bersinergi untuk segera beradaptasi dan merancang pembelajaran secara daring (dalam jaringan).

Pembelajaran online sama halnya dengan pembelajaran offline membutuhkan media pembelajaran untuk meningkatkan tercapainya tujuan pembelajaran. Asal mula kata media yaitu dari bahasa latin yang merupakan jamak dari kata medium bermakna harfiah perantara atau pengantar. Perantara Mahasiswa untuk memahami materi pembelajaran menjadi peranan penting sebagai alat bantu mempermudah proses 


\section{muhadasah \\ Jumal Panditikan abassa arab \\ INSTITUT AGAMA ISLAM SUNAN KALIJOGO MALANG \\ P-ISSN 2622-6723 E-ISSN 2721-9488 \\ Volume 2, Nomor 2 Desember 2020}

pembelajaran yang efektif, kreatif, dan inovatif. Proses pembelajaran ditandai dengan beberapa unsur yaitu tujuan, bahan, metode, media, dan evaluasi. ${ }^{10}$

Para Dosen sudah seharusnya memilih media teknologi informasi untuk pembelajaran online. Kemajuan teknologi memudahkan Mahasiswa dalam pembelajaran sebagian besar Mahasiswa lebih cepat memahami sesuatu hal baru dari teknologi mutaakhir. Peralatan yang digunakan saat pembelajaran online yaitu bisa berupa smartphone, laptop, dan komputer.

Beberapa aplikasi lainnya untuk media pembelajaran yang mengevaluasi atau mengecek pemahaman Mahasiswa salahsatunya yaitu kahoot. Aplikasi ini berbasis games based learing yaitu berbasis kuis yang menarik dan mudah pengaplikasiannya dari segi Para Dosen ataupun Mahasiswa. Kuis ini untuk mengukur kemampuan individu Mahasiswa. Namun tetap terdapat kelemahan dan kelebihan pembelajaran online, berdasarkan hasil penelitian ${ }^{11}$ dari 322 angket kuesioner yang telah diisi Mahasiswa menghasilkan 45\% menyukai pembelajaran online dan 55\% tidak menyukai pembelajaran online. Beberapa hal yang mempengaruhi Mahasiswa yang menyukai pembelajaran online diantaranya pembelajaran berlangsung dengan santai, bermain sambil belajar, dan menyenangkan. Sebaliknya bagi Mahasiswa yang tidak menyukai yaitu karena kuota internet yang habis atau jaringan internet yang lemah selain itu juga bosan belajar dirumah saja. Mahasiswa ada yang lebih suka dijelaskan gurunya secara langsung. Dapat disimpulkan bahwa gaya belajar mempengaruhi kenyamanan belajar secara online atau offline.

\section{Pembelajaran Bahasa Arab Keterampilan Mendengarkan}

Pembelajaran bahasa Arab keterampilan mendengarkan merupakan salah satu dari ketrampilan berbahasa yang wajib dikuasai oleh Mahasiswa dalam belajar bahasa asing. Begitu juga dengan bahasa Arab mempunyai ketrampilan berbahasa yaitu

\footnotetext{
${ }^{10}$ Mujib, F dan Rahmawati, N. Metode Permainan-Permainan Edukatif dalam Belajar Bahasa Arab, (Jogjakarta: Diva Press, 2011), hal.65.

11 Di akses pada tanggal 11 Oktober 2020 \& jam 19.40 WIB di alamat https://jurnaldikpora.jogjaprov.go.id/index.php/jurnalideguru/article/view/136/174. Pujiasih, Erna. 2020. Membangun Generasi Emas Dengan Variasi Pembelajaran Online Di Masa Pandemi Covid-19.
} 


\section{muhadasah \\ Jurnal Pendidikan Bahasa Arab \\ INSTITUT AGAMA ISLAM SUNAN KALIJOGO MALANG \\ P-ISSN 2622-6723 E-ISSN 2721-9488 \\ Volume 2, Nomor 2 Desember 2020}

maharoh 'istima' (mendengarkan), maharoh qiro'ah (membaca), dan maharoh kitabah (menulis). Pembelajaran bahasa untuk keterampilan mendengarkan dibutuhkan untuk memahami suatu percakapan dengan baik dan benar, menurut M.Khalilullah, Fathi Ali Yunus dkk dalam Corinna, D.F. dkk, keterampilan mendengarkan dibagi menjadi empat yaitu: 1) memahami makna secara global, 2) menafsirkan kalimat yang didengar, 3) memberikan analisis terhadap kalimat yang didengar, dan 4) memahami dengan sepenuh hati dari apa yang didengar. ${ }^{12}$ Keterampilan mendengarkan adalah keterampilan pertama sebelum berbicara, membaca, dan menulis. Seperti bayi yang belum bisa memahami bahasa ibunya, setiap hari telinganya akan mendengar kosakata baru dari keluarganya hingga bayi itu bisa berbicara sendiri dan memahami kalimat orang lain.

Keterampilan mendengarkan menurut Ainin, M. dkk ${ }^{13}$ keterampilan yang sangat penting dari keempat keterampilan berbahasa dalam proses pembelajaran bahasa, karena merupakan salah satu bentuk kegiatan dalam berkomunikasi. Beberapa hal yang diukur dari kompetensi keterampilan mendengarkan yaitu:

- Kemampuan mengidentifikasi bunyi huruf

- Kemampuan membedakan bunyi huruf yang mirip,

- Kemampuan memahami arti kosa kata dan frasa,

- Kemampuan memahami kalimat,

- Kemampuan memahami wacana,

- Kemapuan memberikan tanggapan dari isi wacana yang didengarnya

Kemampuan mengidentifikasi bunyi huruf terdapat dalam kajian materi homonym dan homofon, yaitu dimana kata berhomonim itu maknanya berbeda tetapi bentuknya sama. Menurut Taufiqurrochman ${ }^{14}$ Bahasa Indonesia memiliki kata yang berhomonim

12 Di akses pada tanggal 11 Oktober 2020 \& jam 19.30 WIB di alamat https://prosiding-arabum.com/index.php/konasbara/article/view/691. Corinna, D. dkk. 2020. Problematika Pembelajaran Bahasa Arab secara Daring: Studi Kasus Mahasiswa Program Studi Bahasa dan Kebudayaan Arab Universitas Al-Azhar Indonesia.

${ }^{13}$ Ainin, M. dkk., Evaluasi dalam Pembelajaran Bahasa Arab, Cet: I, (Malang: Misykat, 2006), hal.135.

14 Taufiqurrochman. Leksikologi Bahasa Arab. Malang (UIN-Malang Press, 2008), hal.70. 
mempunyai bunyi sama akan tetapi ejaannya berbeda, sedangkan dalam bahasa Arab tidak ada homofon dalam satu kata dengan kata yang lain kecuali kesamaan antara satu kata dengan frase. ${ }^{15} \mathrm{Hal}$ ini tentu dibutuhkan latihan untuk memahami kalimat dan kata yang didengar dalam keterampilan mendengarkan.

Pembelajaran terdahulu menganut sentral pembelajaran klasikal menurut Mujib, F. dan Rahmawati N, yaitu kegiatan mahasiswa di dalam kelas, baik dengan pendekatan tutorial atau cara belajar berpusat pada mahasiswa. ${ }^{16}$ Demikian juga pembelajaran dalam keterampilan mendengarkan secara konvensional penyajiannya seperti para dosen memutarkan lagu, film, video ke mahasiswa dan ada tugas yang harus diberikannya. Ini merupakan metode lama yang seiring berkembangnya zaman sudah jarang digunakan.

Pembelajaran bahasa Arab di Kampus IAI Sunan Kalijogo Malang juga menggunakan media-media aplikatif dari internet sebelum pandemi, termasuk pembelajaran bahasa Arab pada keterampilan mendengarkan, namun ada beberapa hal yang membedakan ketika offline dan online. Ketika offline Para Dosen membutuhkan peralatan seperti LCD dan speaker untuk memutarkan video percakapan langsung dari aplikasi youtube penutur asli dan kami menirukan ujaran atau ungkapannya. Misalnya saat belajar secara langsung lahjah dan gaya bicara orang Arab. Pembelajaran keterampilan mendengarkan secara offline menunjukkan kegiatan belajar mengajar yang interaktif. Ketika online setelah menjelaskan materi dengan zoom meeting kemudian mengecek pemahaman keterampilan mendengarkan dengan menggunakan aplikasi seperti kahoot. Pembelajaran seperti ini menarik bagi siswa karena bisa lebih fokus dengan apa yang didengar secara individu. Tetapi tetap kekurangannya ada pada jaringan internet setiap Mahasiswa. Internet yang tidak lancar bisa menghambat pembelajaran karena menyebabkan keterlambatan dalam mengerjakan kuis keterampilan mendengarkan.

15 idem, hal.70.

${ }^{16}$ Mujib, F dan Rahmawati, N. Metode Permainan-Permainan Edukatif dalam Belajar Bahasa Arab, (Jogjakarta: Diva Press, 2011), hal.28. 


\section{Pemanfaatan Kahoot Sebagai Media Keterampilan Mendengarkan Bahasa Arab}

Kemajuan teknologi saat ini melahirkan banyak aplikasi di smartphone melalui jaringan internet. Kahoot sebagai salah satu teknologi pembelajaran, kahoot merupakan permainan berbasis platform pembelajaran gratis. Menurut website resmi kahoot, platform ini dibuat oleh Morten Versvik, Johan Brand, Jamie Brooker, dan berkerjasama dengan Prof Alf Inge Wang. Bulan September pada tahun 2013 kahoot diluncurkan pertama kali di Norwegia. Kahoot sekarang dimainkan oleh lebih dari 4 miliar orang dari kurang lebih 200 negara. Kahoot diirancang untuk mudah diakses semua orang di seluruh dunia dan siapa saja dapat membuat kuis dalam kahoot tanpa dibatasi untuk tingkat usia atau subjek tertentu. Kemudahan dalam mengaplikasikan kahoot juga dapat dilihat sebagai pengguna tidak perlu mendownload aplikasi kahoot di android, cukup dengan membuka kahoot di web browser sudah bisa digunakan.

Fitur yang dimiliki kahoot selain kuis yaitu games, diskusi dan survei. Games bisa dilakukan dikelas dengan fitur adu cepat benar-salah menjawab soal. Sedangkan kuis bisa disuguhkan dengan dua cara yaitu dipimpin oleh Para Dosen sebagai admin setiap nomor dikerjakan bersama atau selain itu dikerjakan individu dengan batas waktu pengerjaan. Pembelajaran daring (dalam jaringan) seperti ini jelas lebih efektif menggunakan model individu karena keterbatasan ruang tidak dalam kelas di sekolah melainkan pembelajaran dari rumah. Sedangkan diskusi dan survei dalam pembelajaran dapat menyuguhkan gambar/video untuk bahan diskusi. Seluruh fitur kahoot dapat dibuat tidak hanya pertanyaan saja tetapi menyertakan gambar atau video. Pembelajaran menggunakan media kahoot tentu dapat meningkatkan rasa percaya diri Mahasiswa dengan kemampuan yang dimilikinya dan juga mengurangi ketergantungan Mahasiswa terhadap guru, sehingga dapat belajar dimana saja dan kapan saja.

Salah satu nyawa atau inti syarat dari kahoot yaitu mengandalkan koneksi internet karena jaringan yang lemah juga dapat mempengaruhi ketidakberlangsungan pembelajaran menggunakan media kahoot. Inilah yang menjadi kekurangan dari kahoot karena pada dasarnya pertanyaan dalam kuis kahoot hanya bisa dimainkan secara 


\section{muhadasah \\ Jurnal Pendidikan Bahasa Arab \\ INSTITUT AGAMA ISLAM SUNAN KALIJOGO MALANG \\ P-ISSN 2622-6723 E-ISSN 2721-9488 \\ Volume 2, Nomor 2 Desember 2020}

online dengan jaringan internet. Kekurangan media kahoot yang lainnya dari sisi Para Dosen yaitu tidak semua Para Dosen memiliki waktu untuk mengatur dan menyusun rancangan pembelajaran dengan kahoot. Sedangkan dari Mahasiswa kekurangan terlihat dari adanya Mahasiswa yang menggunakan gawai bukan hanya membuka kuis kahoot melainkan games yang lain atau sosial media.

Langkah Mahasiswa untuk mengerjakan jauh lebih mudah, karena tidak perlu mendesain soal. Berikut penjelasan cara mengerjakan kuis dengan media kahoot: 1) Kuis yang sudah disiapkan oleh admin dimana admin adalah Para Dosen diklik play sebagai tanda soal kuis siap untuk dikerjakan, selanjutnya pengaturan mode antara klasik yang dilakukan individu atau mode tim. Kemudian muncul PIN dan link yang akan di bagikan Para Dosen kepada Mahasiswa, 2) Mahasiswa membuka website kahoot.it dan mengakses link atau PIN yang sudah dibagikan, 3) Menulis nama di awal setelah bergabung dalam kuis, 4) Nama akan muncul di monitor Para Dosen sebagai admin, 5) Mode klasik secara individu akan memulai langsung kuis tanpa dioperasikan oleh Para Dosen.

Media kahoot merupakan salah satu contoh pembelajaran yang merupakan bentuk belajar sambil bermain. Pembelajaran dengan model permainan merupakan bagian dari aktivitas atau cara untuk menciptakan metode kreatif yang memudahkan Mahasiswa dalam memahami dan menyerap pengetahuan bahasa Arab. ${ }^{17}$ Media pembelajaran kahoot dapat menciptakan metode kreatif dan memudahkan Mahasiswa memahami dan menyerap pembelajaran bahasa Arab pada keterampilan mendengarkan. Media kahoot menyuguhkan fitur untuk mengunggah video dan gambar sebagai fasilitas mempermudah kegiatan pembelajaran keterampilan mendengarkan.

Pembelajaran bahasa Arab di kampus IAI Sunan Kalijogo Malang telah menerapkan kuis dengan media kahoot untuk keterampilan mendengarkan. Langkah awal membuat kuis untuk mengevaluasi keterampilan mendengarkan yang perlu dipersiapakan yaitu

\footnotetext{
${ }^{17}$ Mujib, F dan Rahmawati, N. Metode Permainan-Permainan Edukatif dalam Belajar Bahasa Arab, (Jogjakarta: Diva Press, 2011), hal.30.
} 
membuat video rekaman suara dengan aplikasi edit video misalnya camtasia, kinemaster, dan adobe premiere. Video selanjutnya di upload ke youtube dan dibutuhkan link URL youtubenya. Ketika kuis berlangsung otomatis tersambung dengan aplikasi youtube.

Keterampilan mendengar bahasa Arab menggunakan media kahoot ketika pembelajaran berbasis online karena pandemi merupakan salah satu solusi untuk tetap menciptakan pembelajaran yang interaktif dan menyenangkan. Mahasiswa terlibat aktif dan responsif dalam pembelajaran dengan media kahoot. Namun ada suatu kendala yang terjadi saat pembelajaran keterampilan mendengarkan bahasa Arab dengan media kahoot berbasis online yaitu: 1) jaringan internet yang lemah kemudian tidak bisa mendeteksi video dalam youtube, 2) backsound suara dari kahoot yang bersamaan dengan suara soal dari video cukup menganggu, dalam hal ini adapun solusinya Mahasiswa dapat mematikan suara saat bermain kuis, 3) Para Dosen tidak bisa membantu secara langsung kesulitan Mahasiswa saat mengerjakan karena tidak bertatap muka.

Penjelasan di atas membahas banyak kekurangan media kahoot dan juga kelebihan yang ditemukan saat pembelajran keterampilan mendengar bahasa Arab. Dalam penerapannya setiap media pembelajaran sudah pasti memiliki dampak positif dan negatif untuk itu Para Dosen sebagai konten creator harus lebih kreatif dan inovatif untuk menggunakan sebuah media pembelajaran keterampilan mendengar di era pandemi. Para Dosen juga harus mempunyai solusi lain ketika terjadi permasalahan saat pembelajaran berbasis media online agar tujuan pembelajaran tetap tercapai.

\section{PENUTUP}

\section{Kesimpulan}

Media Kahoot untuk pembelajaran bahasa Arab salah satunya yaitu mengasah bahasa asing dalam keterampilan mendengarkan. Media kahoot yang digunakan untuk pemnbelajaran keterampilan mendengarkan adalah penggunaan kuis online. Pelaksanaan kuis online dirumah masing-masing Mahasiswa dengan menggunakan alat 
sederhana yaitu smartphone atau laptop individu. Sehingga hal ini memudahkan siswa dalam belajar keterampilan mendengarkan bahasa Arab karena tidak membutuhkan banyak alat. Soal dalam keterampilan mendengarkan yang disajikan langsung bersinergi dengan aplikasi youtube.

Adapun hasil analisis dalam pembahasan penelitian tentang pemanfaatan media kahoot untuk pembelajaran keterampilan mendengarkan bahasa Arab di IAI Sunan Kalijogo Malang yaitu proses meningkatkan kemampuan mahasiswa sebagai subyek pembelajar yang secara aktif melakukan praktek pemanfaatan media kahoot. Belajar efektif dimulai di lingkungan yang berpusat pada diri mahasiswa dan akan berhasil jika diberi kesempatan melalui kegiatan dalam pemanfaatan media kahoot, bila mereka berpartisipasi mereka akan lebih mudah menguasai apa yang telah mereka pelajari. Penggunaan pemanfaatan media kahoot memiliki peran yang sangat penting dalam pembelajaran bahasa Arab dengan dukungan fasilitas yang sudah dipersiapkan sebelumnya.

\section{Saran}

Berdasarkan hasil observasi, penulis menyarankan beberapa hal dalam memaksimalkan penggunaan metode membaca dalam pembelajaran PBA, misalnya:

a. Para Dosen Para Dosenan bahasa Arab hendaknya memberikan sebuah pelatihan untuk dijadikan bahan latihan agar mereka terbiasa dalam penggunaan media kahoot untuk pembelajaran agar metode mengajar menjadi inovatif, sumber referensi menjadi bertambah, waktu menjadi efektif dan efisien.

b. Mahasiswa agar lebih memahami bahwa pemanfaatan media kahoot sangat bermanfaat dalam mendalami media dan meningkatkan minat dan motivasi dalam belajar bahasa Arab. 


\section{DAFTAR PUSTAKA}

Ainin, M. dkk. Evaluasi dalam Pembelajaran Bahasa Arab. Cet; I: Malang: Misykat, 2006

Bagong Suyanto Sutinah, Metode Penelitian Sosial: Berbagai Alternatif Pendekatan, Jakarta: Kencana, 2005

Companykahoot. 2013. History. https://kahoot.com//. (diakses pada tanggal 10 Oktober 2020)

Corinna, D. dkk. 2020. Problematika Pembelajaran Bahas Arab secara Daring: Studi Kasus Mahasiswa Program Studi Bahasa dan Kebudayaan Arab Universitas AlAzhar Indonesia,https://prosiding-arabum.com/index.php/konasbara/article/view/691 (diakses tanggal 11 Oktober 2020)

Dedy Mulyana, Metodologi Penelilian Kualitatif. Bandung: Rosdakarya, 2013

Imran, S. 2014. Fungsi-Fungsi Utama Media Pembelajaran Visual. https://ilmupendidikan.net/pembelajaran/media-pembelajaran/fungsi-fungsi-utama-mediapembelajaran-visual (diakses tanggal 10 Oktober 2020)

Kaunang, S. 2020. Model Pembelajaran Menarik dengan Menggunakan Aplikasi Kahoot Sebagai Bahan Evaluasi Keberhasilan Belajar untuk Mahasiswa. http://ejournal.unima.ac.id/index.php/dilan/article/view/2090/1309 (diakses tanggal 09 Oktober 2020)

Lexy J, Moeleong. Metode Penelitian Kualilatif. Bandung: Remaja Rosdakarya, 2015

Moleong. Metodologi Penelitian Kualitatif. Bandung: Rosdakarya, 2002

Mujib F dan Rahmawati N, Metode Permainan-Permainan Edukatif dalam Belajar Bahasa Arab. Jogjakarta: Diva Press, 2011

Mujib F dan Rahmawati N. Permainan Edukatif Pendukung Pembelajaran Bahasa Arab (2). Jogjakarta: Diva Press, 2012

Nasution. Metode Penelitian Naturalistik Kualitatif. Bandung: Tarsito, 2007

Nur Sholeh dan Ulin Nuha. Pengembangan Kurikulum Bahasa Arab. Jogjakarta: Diva Press, 2013

Pujiasih, Erna. 2020. Membangun Generasi Emas dengan Variasi Pembelajaran Online di Masa Pandemi Covid-19 di https://jurnaldikpora. 
jogjaprov.go.id/index.php/jurnalideguru/article/view/136/174.\(diakses tanggal 11 Oktober 2020)

Taufiqurrochman. Leksikologi Bahasa Arab. Malang: UIN-Malang Press, 2008

Wikipedia. 2020. Pandemi Covid-19 di https://id.wikipedia.org/wiki/Pandemi_COVID19 (diakses tanggal 09 Oktober 2020) 